\title{
Correction
}

\section{Correction: Long Non-Coding RNA and Alternative Splicing Modulations in Parkinson's Leukocytes Identified by RNA Sequencing}

\section{The PLOS Computational Biology Staff}

The images for Figures 2 and 3 are incorrectly switched. The image that appears as Figure 2 should be Figure 3, and the image that appears as Figure 3 should be Figure 2. The figure legends appear in the correct order.

\section{Reference}

1. Soreq L, Guffanti A, Salomonis N, Simchovitz A, Israel Z, et al. (2014) Long Non-Coding RNA and Alternative Splicing Modulations in Parkinson's Leukocytes Identified by RNA Sequencing. PLoS Comput Biol 10(3): e1003517. doi:10.1371/journal.pcbi.1003517
Citation: The PLOS Computational Biology Staff (2014) Correction: Long NonCoding RNA and Alternative Splicing Modulations in Parkinson's Leukocytes Identified by RNA Sequencing. PLoS Comput Biol 10(5): e1003647. doi:10.1371/ journal.pcbi.1003647

Published May 16, 2014

Copyright: (C) 2014 The PLOS Computational Biology Staff. This is an openaccess article distributed under the terms of the Creative Commons Attribution License, which permits unrestricted use, distribution, and reproduction in any medium, provided the original author and source are credited. 